\title{
Evaluation of Five Tropical Grasses for Growing Holstein Heifers ${ }^{1}$
}

\author{
J.A. Yazman, J. Vélez-Santiago, J.A. Arroyo-Aguilú, and \\ R. E. McDowell ${ }^{2,3}$
}

\begin{abstract}
Two-year grazing trials were conducted at the Corozal Agricultural Experiment Substation to determine the availability of five grass species: Tanner (Brachiaria radicans), Signal ( Brachiaria decumbens), Pangola (Digitaria decumbens), Digitaria milanjiana, and Guinea (Panicum maximum), as forage sources for growing Holstein heifers. Species effects were non-significant in average daily gain (ADG) (range .43 to $.51 \mathrm{~kg}$ ). Digitaria milanjiana was best in ADG, but Signal grass was highest in estimated carrying capacity, 5.87 versus 5.2 to $5.7 \mathrm{head} / \mathrm{ha} /$ year for the other four grasses. Variations in ADG were large, both within grasses and within months. ADG was approximately $50 \%$ lower from December to January because of temperature effects on grass growth. All five grasses were deemed acceptable for heifer growth, but Tanner grass is not recommended because of possible toxicity. Dry matter (DM) content was highest from April to September but crude protein (CP) was lowest in this period. The DM content varied from $<20$ to $>30 \%$, thus showing its influence on intake. In July and August, the three grasses averaged $<7 \%$ $\mathrm{CP}$, which may have also affected rate of intake. Under normal temperature and rainfall, maximum temperature had a significant $(P=.01)$ positive correlation with DM content (.64 to .87 ), but a negative correlation with $\mathrm{CP}$ content $(-.26$ to -.79$)$. However, abnormal rainfall had a marked effect on these relations. Correlations of DM or CP contents in harvested samples with ADG were variable, indicating that these measures are relatively unreliable for predicting rate of gain. Estimated intake of DM as \% body weight ranged from 2.9 to $3.1 \%$. On the average, $<6 \%$ of available pasture grass DM was utilized. Considering costs, such a low rate of use is not economical; hence, the need for further research on management of fertilized tropical grass pastures for most efficient use of available biomass.
\end{abstract}

\section{INTRODUCTION}

For nearly three decades, scientists from the University of Puerto Rico Agricultural Experiment Station and the United States Department of Agriculture have evaluated numerous grasses for forage production in Puerto Rico. Most of the trials incorporated the use of fertilizer in pasture-based feeding systems, designed to maximize production on limited and expensive land. Certain grasses proved more suitable than

${ }^{1}$ Manuscript submitted to Editorial Board December 2, 1981.

${ }^{2}$ Data are taken in part from a thesis submitted by the senior author to the Graduate Faculty, Cornell University, Ithaca, N.Y., in partial fulfillment of the requirements for the degree of Doctor of Philosophy.

${ }^{3}$ Animal Scientist, Winrock International Research and Training Center, Morrilton, AR; Associate Agronomist, Corozal Substation; Nutritionist, Animal Industry Department, Agricultural Experiment Station, University of Puerto Rico, Río Piedras, P.R.; and Professor of International Animal Science, Cornell University, Ithaca, N.Y., respectively. The authors are grateful to Sucesión Fonalledas, Hato Rey, P.R., for providing the heifers and partial financial support. 
others: estimated carrying capacity ranged from 5.2 to 7.4 head/ha and from 712 to $1514 \mathrm{~kg}$ of animal gain/ha/year $(5,23)$. In general, grasses proved to have one or more limitations, such as low response to fertilizer, drought effects, disease and insect susceptibility, slow rate of establishment, and low acceptance by grazing animals. The studies led to some general conclusions: wide utilization of several grass species on farms will control or reduce potential losses by disease or pests in one or more grasses; different management systems would be required for extensive farm use because of variations in soil types and rainfall distribution; and selection programs with cultivars will improve yield and nutritive value. Numerous experiences in the forage program $(3,4,5,6,7,13,22,23,25)$ clearly show the need for continuity in forage research.

The objectives of this study were to evaluate grass species and selected cultivars previously found suitable for animal utilization; to determine the relation of environment to nutritive value and forage yield; and to determine rate of utilization of pasture grass dry matter (PGDM) by grazing cattle.

\section{MATERIALS AND METHODS}

Two trials were conducted over a 2-year period (March 29, 1972, to March 28, 1973; and February 6, 1974, to January 4, 1975) at the Corozal Agricultural Experiment Substation, at about 214-m elevation in the humid mountainous region of Puerto Rico (lat. $18^{\circ} 20^{\prime} \mathrm{N}$. and long. $66^{\circ} 22^{\prime}$ W.). Mean monthly maximum and minimum temperatures ranged from 27 to $31^{\circ} \mathrm{C}$, and from 17 to $20^{\circ} \mathrm{C}$, respectively (table 1). Rainfall averaged about $1900 \mathrm{~mm}$ per year with no distinct dry season.

\section{SOILS AND PASTURES}

The soil is a deep, red, acid, moderately well-drained Corozal clay (Ultisol), with an average slope of $20 \%$ and a $\mathrm{pH}$ of 5.0 . The soil was limed to about $\mathrm{pH}$, and fertilized at the equivalent of $2240 \mathrm{~kg} / \mathrm{ha} /$ year, with a commercial analysis 15-5-10.

The grasses were Tanner (Brachiaria radicans), Signal (Brachiaria decumbens), Pangola (Digitaria decumbens), Digitaria milanjiana, and Guinea (Panicum maximum). Signal, Pangola, and Guinea were selected cultivars tested at Corozal, with the main emphasis on increased dry matter (DM) yields.

The five grasses were distributed over plots in a randomized block design, five plots per block, each .4 ha with one grass (total 20 plots on 8 ha). The four plots within each grass were grazed rotationally for 7 days followed by 21 days of regrowth. All grasses were grazed during trial 1, but Tanner grass was excluded from trial 2 principally because of toxicity problems. 
Mineralized salt blocks and water were available in all plots at all times.

\section{ANIMALS}

Heifers, principally of Holstein breeding and 9-10 mo of age, were assigned as testers at the rate of eight per grass for a stocking rate equivalent to five head per ha. Additional heifers were added under a put and take (PT) system, when grass growth exceeded tester capacity. The heifers were weighed at 7-day intervals following a 2 -hr removal from the plots.

\section{FORAGE EVALUATION}

Forage availability and nutritive value were estimated from samplings before and after grazing. Animal grazing was simulated by hand-plucking,

TABLE 1.-Monthly temperature and rainfall in Corozal Substation (5-year average)

\begin{tabular}{|c|c|c|c|c|}
\hline \multirow{2}{*}{ Month } & \multicolumn{2}{|c|}{ Temperature $\left({ }^{\circ} \mathrm{C}\right)$} & \multirow{2}{*}{$\begin{array}{c}\text { Rainfall } \\
\text { (mm) }\end{array}$} & \multirow{2}{*}{$\begin{array}{l}\text { Days rainfall } \\
>2.5 \mathrm{~mm}\end{array}$} \\
\hline & Maximum & Minimum & & \\
\hline January & 27.0 & 17.4 & 158 & 11 \\
\hline February & 27.4 & 17.1 & 114 & 7 \\
\hline March & 28.1 & 17.4 & 110 & 8 \\
\hline April & 28.9 & 17.8 & 125 & 9 \\
\hline May & 29.8 & 19.4 & 208 & 13 \\
\hline June & 31.1 & 20.4 & 97 & 9 \\
\hline July & 30.2 & 20.6 & 140 & 12 \\
\hline August & 30.6 & 20.6 & 135 & 10 \\
\hline September & 30.9 & 20.4 & 124 & 10 \\
\hline October & 29.0 & 19.3 & 241 & 13 \\
\hline November & 28.9 & 19.3 & 293 & 14 \\
\hline December & 27.1 & 18.2 & 178 & 12 \\
\hline Mean & 29.1 & 19.0 & 160 & 11 \\
\hline Total & & & 1922 & 128 \\
\hline
\end{tabular}

taken randomly across plots. Total DM and crude protein (CP) yields were determined from cuttings of $.91 \mathrm{~m}^{2}$ quadrats at $5 \mathrm{~cm}$ above ground level. Five quadrats were harvested before and after grazing. The harvested material was used for estimates of PGDM available to grazing and for determination of nitrogen $(\mathrm{N})$ with a Technicon ${ }^{4}$ auto-analyzer. $\mathrm{CP}$ content was calculated as $\mathrm{N} \times 6.25$. Maximum and minimum temperatures and rainfall were recorded daily.

\footnotetext{
${ }^{4}$ Trade names in this publication are used only to provide specific information. Mention of a trade name does not constitute a warranty of equipment or materials by the Agricultural Experiment Station of the University of Puerto Rico, nor is this mention a statement of preference over other equipment or materials.
} 
METHODS OF ANALYSIS

A one-way analysis of variance model was used for testing grass effects on average daily gain (ADG) and total gain (19). A two-way model was employed for tests of interaction effects between grasses and weight periods (seasons). Regressions and correlations were used for estimates of the relationship between environmental and pasture variables and animal weight periods (9).

\section{RESULTS AND DISCUSSION}

\section{AVERAGE DAILY GAIN BY TESTERS}

Differences in ADG among heifers on different grasses during the 2 trials were small and non-significant (table 2). ADG was highest for Digitaria milanjiana in both years. There were, however, reservations

TABLE 2.-Body weights, average daily gains, and standard deviations for heifers during trials 1 and 2

\begin{tabular}{|c|c|c|c|c|c|c|c|c|c|}
\hline \multirow{3}{*}{ Grass } & \multicolumn{4}{|c|}{ Trial I (kg) } & \multicolumn{5}{|c|}{ Trial $2(\mathrm{~kg})$} \\
\hline & \multicolumn{2}{|c|}{ Body weight $^{1}$} & \multirow{2}{*}{$\mathrm{ADG}$} & \multirow{2}{*}{$\mathrm{SD}$} & \multicolumn{2}{|c|}{ Body weight } & \multirow{2}{*}{ Gain } & \multirow{2}{*}{$\mathrm{ADG}$} & \multirow{2}{*}{ SD } \\
\hline & Initial & Final & & & Initial & Final & & & \\
\hline Tanner & 189 & 364 & .48 & .05 & - & - & - & - & - \\
\hline Signal & 191 & 357 & .45 & .05 & 166 & 318 & 152 & .45 & .05 \\
\hline Pangola & 207. & 376 & .46 & .06 & 166 & 318 & 152 & .45 & .05 \\
\hline D. milanjiana & 194 & 380 & .51 & .07 & 166 & 322 & 157 & .47 & .04 \\
\hline Guinea & 189 & 359 & .47 & .03 & 166 & 311 & 146 & .43 & .05 \\
\hline $\mathrm{LSD}^{2}$ & & & .06 & & & & & .07 & \\
\hline
\end{tabular}

${ }^{1}$ Means of 8 animals per grass.

${ }^{2}$ Least significant difference.

over the superiority of this grass when days of grazing by PT heifers were considered. The lower number of days for PT heifers on this grass may have affected selection and thereby influenced ADG. From May to October (trial 1), there were 66 days of PT on Pangola grass, 75 days on Tanner and Digitaria milanjiana grasses, 269 days on Guinea grass, and 315 days on Signal grass. In 1973, there was much less use of the PT system. However, no PT heifers were used on Digitaria milanjiana. When comparisons were made on estimated carrying capacity (animals/ ha/year), Signal grass was highest with 2135 animal-days or 5.87 heifers/ ha/year. Of the total animal days generated on Signal grass, 15\% was accounted for by PT heifers added from June to October. Guinea grass supported 2,089 animal-days for a carrying capacity of 5.74 animals/ha/ year. Because of fewer days of P'T use, the carrying capacity of Tanner, Digitaria milanjiana, and Pangola grasses was 5.21, 5.20, and 5.18 animals/ha, respectively. The conclusion was that, when stocking rates 
were restricted to testers, differences in ADG among grasses would have been less.

ADG $(.43$ to $.51 \mathrm{~kg})$ and gains/ha/year $(874$ to $979 \mathrm{~kg}$ ) for the five grasses were somewhat lower than in previous trials with Guinea and Pangola grasses on a farm near Orocovis $(6,7,22)$. Gains during the 2 trials were similar for the same five grasses at Corozal (5). Most of the trials using PT animals incorporated gains of these animals in estimates of carrying capacity. PT heifers were excluded from estimates in this study because of primary interest in heifer development for farm management over sustained periods.

ADG obtained on all five grasses would be sufficient for growing Holstein heifers which could be bred for calving by 28 to 30 mo of age and weighing at least $450 \mathrm{~kg}$ (14). However, Tanner grass would not be recommended until there is a better understanding of its influence on animal health. Although ADG was good with Digitaria milanjiana, its use may be limited to certain soils. At Corozal, it was found to be shallowrooted, which made it subject to wide variation in forage yields and to uprooting by grazing animals (5).

Effects of season on ADG varied considerably within grasses and months (table 3). ADG ranged from 0 to $1.0 \mathrm{~kg}$. Because of the high variability among months, it is difficult to predict seasonal trends beyond stating that $\mathrm{ADG}$ from December to January would be approximately $50 \%$ lower than for most other month. The low values for December to January were attributed to lower day-length, which affected rate of regrowth $(13,22)$. Fluctuations in ADG during the other months was associated with rainfall distribution, grass maturity, and variation in selection because of presence or absence of PT heifers.

In neither trial, did mean monthly temperatures deviate significantly from the previous 5-year average, although the maximum temperatures during trial 1 averaged $.4^{\circ} \mathrm{C}$ below normal (table 1 ). Rainfall was highly variable. In $1972,55.7 \%$ of the $1729 \mathrm{~mm}$ fell from September to November, while the period from January to May was drier than normal. Total rainfall in 1973 was $2026 \mathrm{~mm}$, slightly above the 5-year average of 1922 $\mathrm{mm}$, but monthly values deviated widely from the long-term average. Rainfall from February to June was only $57 \%$ of that expected; June was especially dry with $8 \%$ of normal rainfall.

From a 2-way analysis of variance for interaction effects of grasses and 28-day periods, the mean square for periods and grass $\times$ period interactions was significant $(\mathrm{P}=.01)$ in both trials. This showed that, although variations in ADG between grasses were not important throughout the trials, there was a strong tendency for $A D G$ to vary between periods within a given grass, and between grass $\times$ period subclasses. The standard deviations of the means for ADG by period for Digitaria milanjiana and 
Signal grasses were the largest in trial 1, indicating perhaps more variability for promoting animal gains for these grasses. This must be considered a generality, as the rankings in standard deviations were different in trial 2 (table 3). Alternate periods of low high ADG suggested compensatory gains following periods of below average gains. The inconsistent patterns in ADG indicated that stands of mixed grasses should be recommended. This hypothesis is supported by other studies $(2,3,8,11$, $17,18)$.

TABLE 3.-Means and standard deviations for average daily gains by periods and grass specimens in trials 1 and 2

\begin{tabular}{|c|c|c|c|c|c|c|c|c|c|c|}
\hline \multirow{2}{*}{ Month } & \multicolumn{5}{|c|}{ Trial 1 by grass ${ }^{1}$} & \multicolumn{4}{|c|}{ Trial 2 by grass ${ }^{1}$} & \multirow{2}{*}{ Mean $^{3}$} \\
\hline & $\mathrm{T}$ & $\mathrm{S}$ & $\mathrm{P}$ & D & G & S & $P$ & $\mathrm{D}$ & G & \\
\hline & \multicolumn{10}{|c|}{$\mathrm{kg}$} \\
\hline April $^{2}$ & .75 & .80 & .64 & .84 & .72 & .39 & .35 & .26 & .30 & .54 \\
\hline May & .49 & .44 & .61 & .63 & .63 & .47 & .65 & .61 & .56 & .58 \\
\hline June & .31 & .18 & .26 & .41 & .03 & .69 & .52 & .77 & .89 & .47 \\
\hline July & .42 & .56 & .36 & .32 & .32 & .65 & .61 & .67 & .07 & .45 \\
\hline August & .43 & .24 & .55 & .47 & .56 & .68 & .53 & .51 & .89 & .55 \\
\hline September & .30 & .25 & .24 & .50 & .34 & .47 & .42 & .48 & .63 & .42 \\
\hline October & .56 & .38 & .55 & .26 & .16 & .78 & .60 & .60 & .45 & .47 \\
\hline November & .45 & .51 & .63 & .78 & .53 & .57 & .32 & .39 & .66 & .55 \\
\hline December & .11 & .10 & .09 & .19 & .26 & .07 & .41 & .25 & .19 & .20 \\
\hline January & .64 & .28 & .44 & .29 & .44 & .12 & .11 & .10 & .15 & .24 \\
\hline February & .66 & .64 & .62 & .74 & .76 & .33 & .62 & .40 & .16 & .53 \\
\hline March & .26 & .52 & .33 & .33 & .50 & .22 & .29 & .57 & .26 & .38 \\
\hline April & .89 & 1.00 & .71 & .86 & .83 & - & - & - & - & - \\
\hline Mean & .48 & .45 & .46 & .51 & .47 & .45 & .45 & .47 & .43 & - \\
\hline SD & .28 & .33 & .29 & .32 & .28 & .28 & .22 & .25 & .33 & - \\
\hline
\end{tabular}

${ }^{1}$ T, Tanner; S, Signal; P, Pangola; D, Digitaria milanjiana; G, Guinea.

${ }^{2} 28$-day periods.

${ }^{3}$ Average of 4 grasses common to both trials.

\section{FORAGE DRY MATTER AND CRUDE PROTEIN CONTENT}

$\mathrm{DM}$ and CP estimates for forages harvested at $5 \mathrm{~cm}$ above ground level before grazing are in tables 4 and 5 . The overall monthly means showed fluctuations with season. DM content was highest from April to September; however, this was the lowest period for CP. Hand plucked (HP) samples showed similar trends with season (24). DM of HP samples was 23 to $25 \%$ lower than that of harvested samples, but CP content averaged 40 to $50 \%$ higher.

Assuming that DM contents of $<20$ or $>30 \%$ may cause some limitations in forage utilization (14), $22 \%$ of the samples were $<20 \%$ in DM and 
TABLE 4.-Average dry matter content as determined from harvested samples taken before grazing

\begin{tabular}{|c|c|c|c|c|c|c|c|c|c|c|}
\hline \multirow{2}{*}{ Month } & \multicolumn{5}{|c|}{ Trial 1 by grass ${ }^{1}$} & \multicolumn{4}{|c|}{ Trial 2 by grass ${ }^{1}$} & \multirow{2}{*}{ Mean $^{3}$} \\
\hline & $\mathrm{T}$ & $\mathrm{s}$ & $\mathrm{P}$ & $\mathrm{D}$ & G & S & $\mathrm{P}$ & $\mathrm{D}$ & $\mathrm{G}$ & \\
\hline & \multicolumn{10}{|c|}{$\%$} \\
\hline April $^{2}$ & 20.4 & 28.2 & 27.4 & 22.4 & 21.5 & 29.2 & 34.4 & 34.9 & 25.0 & 27.9 \\
\hline May & 26.2 & 27.3 & 31.1 & 26.7 & 20.6 & 29.4 & 30.7 & 32.7 & 29.1 & 28.5 \\
\hline June & 28.1 & 32.3 & 31.1 & 33.7 & 25.8 & 25.6 & 26.7 & 29.0 & 26.6 & 28.9 \\
\hline July & 27.9 & 31.4 & 30.1 & 31.7 & 19.1 & 34.2 & 31.4 & 35.1 & 18.0 & 28.9 \\
\hline August & 32.7 & 35.8 & 31.3 & 36.2 & 20.2 & 28.2 & 27.6 & 26.2 & 18.3 & 28.0 \\
\hline September & 25.0 & 27.9 & 30.5 & 30.8 & 20.4 & 24.4 & 23.1 & 25.1 & 19.6 & 25.2 \\
\hline October & 21.2 & 21.4 & 23.9 & 23.4 & 21.6 & 21.5 & 21.8 & 20.8 & 19.3 & 21.7 \\
\hline November & 20.4 & 20.9 & 22.5 & 20.3 & 20.9 & 17.2 & 18.0 & 17.8 & 18.3 & 19.5 \\
\hline December & 21.2 & 23.4 & 27.2 & 20.2 & 20.3 & 18.5 & 18.7 & 18.0 & 19.9 & 20.8 \\
\hline January & 14.5 & 19.5 & 22.4 & 17.5 & 16.7 & 20.9 & 21.9 & 19.0 & 21.0 & 19.9 \\
\hline February & 17.2 & 22.3 & 22.5 & 22.2 & 19.4 & 22.5 & 26.3 & 26.1 & 28.0 & 23.7 \\
\hline March & 16.7 & 23.8 & 26.6 & 21.5 & 19.9 & 21.3 & 23.2 & 22.5 & 24.1 & 22.9 \\
\hline April & 16.1 & 21.0 & 21.7 & 19.6 & 19.8 & - & - & - & - & - \\
\hline Mean & 22.1 & 25.8 & 26.8 & 25.1 & 20.5 & 24.4 & 25.3 & 25.6 & 22.3 & 24.4 \\
\hline
\end{tabular}

${ }^{1}$ T, Tanner; S, Signal; P, Pangola; D, Digitaria milanjiana; G, Guinea.

${ }^{2} 28$-day periods.

${ }^{3}$ Average of 4 grasses common to both trials.

TABLE 5.-Average crude protein content as determined from harvested samples taken before grazing

\begin{tabular}{|c|c|c|c|c|c|c|c|c|c|c|}
\hline \multirow{2}{*}{ Month } & \multicolumn{5}{|c|}{ Trial 1 by grass ${ }^{1}$} & \multicolumn{4}{|c|}{ Trial 2 by grass ${ }^{1}$} & \multirow{2}{*}{ Mean $^{3}$} \\
\hline & $\mathrm{T}$ & S & $\mathrm{P}$ & $\mathrm{D}$ & G & $\mathrm{S}$ & $\mathrm{P}$ & $\mathrm{D}$ & G & \\
\hline & \multicolumn{10}{|c|}{$\%$} \\
\hline April $^{2}$ & 7.7 & 6.6 & 10.2 & 10.7 & 10.6 & 11.6 & 13.0 & 11.4 & 10.4 & 10.6 \\
\hline May & 7.5 & 8.6 & 9.9 & 10.8 & 8.2 & 8.4 & 10.9 & 11.3 & 8.4 & 9.6 \\
\hline June & 9.6 & 8.3 & 10.6 & 9.7 & 10.9 & 9.9 & 12.1 & 11.6 & 10.6 & 10.5 \\
\hline July & 6.7 & 7.0 & 8.8 & 8.6 & 13.4 & 5.8 & 6.1 & 6.8 & 9.5 & 8.3 \\
\hline August & 5.4 & 6.2 & 7.0 & 7.9 & 11.5 & 5.9 & 6.9 & 7.3 & 8.0 & 7.6 \\
\hline September & 9.6 & 9.1 & 8.9 & 10.4 & 10.4 & 9.2 & 9.9 & 11.3 & 10.5 & 10.0 \\
\hline October & 8.8 & 9.5 & 9.4 & 11.0 & 7.6 & 10.6 & 11.5 & 12.7 & 13.1 & 10.7 \\
\hline November & 8.9 & 9.5 & 9.9 & 11.5 & 7.7 & 8.9 & 9.6 & 10.4 & 10.6 & 9.7 \\
\hline December & 10.5 & 9.5 & 9.9 & 11.9 & 10.1 & 9.4 & 10.1 & 10.9 & 10.8 & 10.3 \\
\hline January & 12.0 & 11.0 & 11.3 & 13.1 & 11.0 & 9.9 & 10.6 & 11.3 & 11.1 & 11.2 \\
\hline February & 13.1 & 11.7 & 12.1 & 14.0 & 11.4 & 9.8 & 11.1 & 11.2 & 9.9 & 11.4 \\
\hline March & 13.9 & 13.1 & 12.5 & 14.5 & 13.5 & 11.6 & 11.5 & 12.6 & 12.4 & 12.7 \\
\hline April & 15.8 & 12.7 & 14.4 & 15.9 & 12.4 & - & - & - & - & - \\
\hline Mean & 10.0 & 9.4 & 10.3 & 11.5 & 10.7 & 9.3 & 10.3 & 10.7 & 10.4 & - \\
\hline
\end{tabular}

${ }^{1}$ T, Tanner; S, Signal; P, Pangola; D, Digitaria milanjiana; G, Guinea.

${ }^{2} 28$-day periods.

${ }^{3}$ Average of 4 grasses common to both trials. 
$18 \%$ were $>30 \%$ (table 4 ). DM content $>30 \%$ could have been offset by selective grazing. As indicated by lower DM in HP samples, low DM could have influenced intake level and ADG. Signal, Pangola, and Tanner grasses had CP contents of $<7.0 \%$ in July and August, the level which Humphreys (11) and McDowell (14) cited as the level when forage DM intake may be restricted because of lack of $\mathrm{N}$ in the rumen. As with DM estimates, opportunity for selection may have permitted forage intake with $>7.0 \% \mathrm{CP}$.

\section{ENVIRONMENTAL EFFECTS ON DRY MATTER AND CRUDE PROTEIN}

To determine probable influence of temperature and rainfall on grass DM and CP contents, correlations were made between weather variables and $\mathrm{DM}$ or $\mathrm{CP}$ contents, using 28-day average maximum and minimum temperatures, total period rainfall or days with $>2.5 \mathrm{~mm}$ of rain. The associations of estimated weather conditions and DM or CP were highly variable between trials. During trial 1, maximum temperature had a high positive correlation $(\mathrm{P}<.01)$, with $\mathrm{DM}$ content for all grasses (table 6). Minimum temperature also showed a positive relation to DM content, but the correlations between DM content and rainfall were low. In trial 2 , the correlations between DM and temperature were erratic, but there was a high negative relation with DM and the 2 measures of rainfall. CP was negatively correlated with all variables, but temperature appeared to have more effect than rainfall.

The correlations in table 6 indicated that for an average of normal years in Puerto Rico, monthly variations in temperature could be utilized for determining expected changes in DM or CP contents of forages. Abnormal rainfall distribution, such as occurred during 1973, will tend to mask the temperature relation to DM or CP contents of forages.

\section{RELATION OF AVERAGE DAILY GAIN TO DRY MATTER AND CRUDE PROTEIN}

The relation of DM or CP contents within grass and across grasses to ADG by testers, was determined by regression analyses. ADG of individual heifers were used in the 12 or 13 periods instead of average values for ADG. The negative regressions (slope) and correlations for trial 1 (table 7) showed that DM content influenced ADG to a significant degree except for Digitaria milanjiana. The negative regressions and correlations also implied some factor associated with DM restricted intake and/ or utilization of the consumed forage. Most likely, an increase in grass cell wall $(\mathrm{CW})$ content with increasing temperature and light intensity resulted in lowered DM intake $(8,21)$. In trial 2 , the relation of DM and ADG had no discernible pattern. Except for Guinea grass, interpretation of the association of DM and ADG could be directly opposite to that in 
TABLE 6.-Simple correlation coefficients between temperature and rainfall with dry matter and crude protein in harvested samples

\begin{tabular}{|c|c|c|c|c|c|c|c|c|}
\hline \multirow{3}{*}{ Grass } & \multicolumn{4}{|c|}{ Trial $1^{1}$} & \multicolumn{4}{|c|}{ Trial $2^{2}$} \\
\hline & \multicolumn{2}{|c|}{ Temperature } & \multicolumn{2}{|c|}{ Rainfall } & \multicolumn{2}{|c|}{ Temperature } & \multicolumn{2}{|c|}{ Rainfall } \\
\hline & Max. & Min. & Daily & $2.5 \mathrm{~mm}$ & Max. & Min. & Daily & $2.5 \mathrm{~mm}$ \\
\hline \multicolumn{9}{|c|}{ Dry matter } \\
\hline Tanner & $.87^{* *}$ & .76 & -.17 & 0.03 & - & - & - & - \\
\hline Signal & $.71^{* *}$ & .52 & -.35 & -.26 & $.64^{*}$ & .22 & -.50 & $-.61^{* *}$ \\
\hline Pangola & $.64^{* *}$ & .43 & -.24 & -.19 & .38 & -.12 & $-.59^{*}$ & $-.68^{* *}$ \\
\hline D. milanjiana & $.82^{* *}$ & $.67^{* *}$ & -.26 & -.15 & .52 & .02 & -.51 & $-.75^{* *}$ \\
\hline Guinea & $.65^{* * 3}$ & .34 & -.05 & -.18 & -.22 & $-.67^{*}$ & $-.57^{*}$ & $-.67^{* *}$ \\
\hline All & $.64^{* *}$ & $.50^{* *}$ & $\begin{array}{l}-.20 \\
\text { Crud }\end{array}$ & $\begin{array}{l}-.06 \\
\text { protein }\end{array}$ & $.35^{*}$ & -.07 & $-.52^{* *}$ & $-.53^{* *}$ \\
\hline Tanner & $-.66^{* *}$ & $-.72^{* *}$ & -.08 & -.27 & - & - & - & - \\
\hline Signal & $-.70^{* *}$ & $-.66^{* *}$ & .07 & -.14 & $-.56^{*}$ & $-.65^{*}$ & -.04 & -.05 \\
\hline Pangola & $-.61^{* 4}$ & $-.78^{* *}$ & $-.26 * *$ & -.45 & -.43 & $-.63^{*}$ & -.15 & -.21 \\
\hline D. milanjiana & $-.79^{* *}$ & $-.80^{* *}$ & .00 & -.19 & -.46 & -.52 & .00 & -.04 \\
\hline Guinea & -.26 & -.33 & -.49 & -.49 & -.29 & -.17 & .14 & .16 \\
\hline All & $-.58 * *$ & $-.63^{* *}$ & -.13 & $-.28^{*}$ & $-.42 * *$ & $-.49 * *$ & -.02 & -.05 \\
\hline
\end{tabular}

${ }^{1}$ Number degrees of freedom within species 13, across species 65 .

${ }^{2}$ Number degrees of freedom within species 12, across species 48 .

${ }^{3}$ Significant at the $1 \%$ level.

${ }^{4}$ Significant at the $5 \%$ level.

TABLE 7.-Regression statistics and correction coefficients relating average daily gain to dry matter in harvested samples

\begin{tabular}{lcccc}
\hline & \multicolumn{3}{c}{ Regression statistics } & \multirow{2}{*}{ Correlation } \\
\cline { 2 - 3 } & Intercept & Slope & F-Value & \\
\cline { 2 - 3 } Tanner & \multicolumn{3}{c}{ Trial $1^{1}$} \\
Signal & $.842^{* * 2}$ & $-.016^{* *}$ & $10.56^{* * *}$ & $-.31^{* *}$ \\
Pangola & $.809^{* *}$ & $-.014^{* 3}$ & $4.60^{*}$ & $-.21^{*}$ \\
D. milanjiana & $1.058^{* *}$ & $-.022^{* *}$ & $8.64^{* *}$ & $-.28^{* *}$ \\
Guinea & .677 & -.007 & 1.54 & -.12 \\
& $1.557^{* *}$ & $-.053^{* *}$ & $15.75^{* *}$ & $-.37^{* *}$ \\
All & & & & \\
& $.756^{* *}$ & $-.012^{*}$ & $21.29^{* *}$ & $-.20^{* *}$ \\
Signal & & Trial $2^{4}$ & & $.34^{* *}$ \\
Pangola & -.026 & $.020^{* *}$ & $12.15^{* *}$ & $.29^{* *}$ \\
D. milanjiana & .116 & $.013^{* *}$ & $8.65^{* *}$ & $.31^{* *}$ \\
Guinea & .129 & $.013^{* *}$ & $10.18^{* *}$ & -.02 \\
All & $.462^{* *}$ & -.001 & .02 & $.23^{* *}$ \\
\hline
\end{tabular}

${ }^{1}$ Number of degrees of freedom within species 104, across species 520.

${ }^{2}$ Significant at the $1 \%$ level.

${ }^{3}$ Significant at the $5 \%$ level.

${ }^{4}$ Numbers of degrees of freedom within species 96 , across species 384 . 
trial 1, because of the positive values for regressions and correlations in trial 2. The regressions and correlations for $\mathrm{CP}$ and $\mathrm{ADG}$ were as variable as the values for DM (24).

The conclusion is that DM and CP contents of forages within the range of estimates for harvested samples are unreliable for predicting animal gains. Johnstone-Wallace and Kennedy (12) and Hardison et al. (10) showed that clipped grass was not satisfactory for estimating the diet of grazing steers in temperate forages. Tayler and Deriaz (20), using rumenfistulated steers, found that in vitro true digestibility of ryegrass DM selected by the animals was higher than digestibility projected from harvested samplings. Thus, it appeared that as an important adaptive mechanism heifers kept on grazing, without supplementation, selected plant components to compensate for $\mathrm{CP}$ and DM contents. Also, estimates of animal performance on the basis of harvested samples, without consideration of the effects of stocking rate, will lack accuracy because of the ability of the animals to select. This will be the case more often for tropical than for temperate grasses because of wide variations in grass quality in different layers of the sward.

\section{PASTURE GRASS DRY MATTER AND CRUDE PROTEIN AVAILABLE FOR GRAZING}

Estimated quantities of PGDM and pasture grass crude protein (PGCP) available/animal-day were developed from DM or CP yields/ha, as estimated from area yields divided by number of animals on pastures. Tables 8 and 9 show the DM or CP available/head/day. There were broad variations among grasses and among months within grasses for both DM and CP. Seasonal trends were not as distinct as those in DM and $\mathrm{CP}$ contents. In general, the high period for PGDM and PGCP was from March to June, followed by a gradual decline to a low in December to March. PGDM available for grazing does not appear to be a reliable index of potential growth rate of heifers. Digitaria milanjiana and Tanner grasses were lowest in the amount available, but supported the highest ADG in trial 1. The correlations of PGDM and ADG were also highly variable. $A D G$ by testers was significantly correlated $(P=.01)$ to available PGDM for Guinea grass in trial 1, but not for the other grasses, whereas the reverse was the case in trial 2. A possible explanation is that in trial 1 the number of days for PT heifers was highest for Guinea grass. The higher stocking rate may have stimulated the growth rate of Guinea grass.

These evaluations strongly indicate that quantitative estimates are less reliable for predicting the utilization of tropical grasses by grazing animals than for temperate forages, probably because of differences in CW content which will influence intake $(2,21)$. 
TABLE 8.-Estimated available pasture grass dry matter in trials 1 and 2

\begin{tabular}{|c|c|c|c|c|c|c|c|c|c|c|}
\hline \multirow{2}{*}{ Month } & \multicolumn{5}{|c|}{ Trial 1 by grass ${ }^{1}$} & \multicolumn{4}{|c|}{ Trial 2 by grass ${ }^{1}$} & \multirow{2}{*}{ Mean $^{2}$} \\
\hline & $\mathrm{T}$ & $\mathrm{s}$ & $\mathrm{P}$ & $\mathrm{D}$ & G & $\mathrm{S}$ & $\mathrm{P}$ & D & G & \\
\hline & \multicolumn{10}{|c|}{$\mathrm{kg} /$ animal/day } \\
\hline April & $171^{3}$ & 175 & 198 & 126 & 336 & 231 & 261 & 195 & 267 & 224 \\
\hline May & $203^{* 4}$ & 190 & 191 & $146^{*}$ & $241^{*}$ & 228 & 238 & 177 & 293 & 213 \\
\hline June & $188^{*}$ & $207^{*}$ & $202^{*}$ & $188^{*}$ & $140^{*}$ & 194 & 232 & 198 & 218 & 197 \\
\hline July & $156^{*}$ & $163^{*}$ & $154^{*}$ & $194^{*}$ & $99^{*}$ & 244 & 258 & 174 & 123 & 176 \\
\hline August & 137 & $183^{*}$ & 187 & 200 & $262^{*}$ & 201 & 227 & 138 & 139 & 192 \\
\hline September & 136 & $187^{*}$ & 195 & 128 & $227^{*}$ & 170 & 204 & 152 & 170 & 179 \\
\hline October & 144 & $137^{*}$ & 189 & 103 & $132^{*}$ & 177 & 220 & 132 & 170 & 158 \\
\hline November & 138 & $151^{*}$ & 193 & 102 & $192^{*}$ & 171 & 198 & 124 & 210 & 168 \\
\hline December & 119 & 150 & 159 & 89 & 83 & 143 & 162 & 120 & 173 & 135 \\
\hline January & 123 & 123 & 151 & 84 & 186 & 152 & 156 & 109 & 176 & 142 \\
\hline February & 120 & 128 & 130 & 87 & 203 & $191^{*}$ & $209^{*}$ & 190 & $234^{*}$ & 172 \\
\hline March & 127 & 135 & 132 & 73 & 232 & $208^{*}$ & 195 & 164 & $256^{*}$ & 174 \\
\hline April & 153 & 147 & 178 & 93 & 257 & - & - & - & - & - \\
\hline Mean & 146 & 160 & 174 & 124 & 199 & 192 & 213 & 156 & 202 & - \\
\hline
\end{tabular}

${ }^{1}$ T, Tanner; S, Signal; P, Pangola; D, Digitaria milanjiana; G, Guinea.

${ }^{2}$ Average for 4 grasses common to both trials.

${ }^{3}$ Estimated from total pasture grass dry matter and animal days per 28-day period.

${ }^{4}$ Designates periods when put and take heifers were used.

TABLE 9.-Estimated utilization of available pasture grass dry matter by months in trials 1 and 2

\begin{tabular}{|c|c|c|c|c|c|c|c|c|c|c|}
\hline \multirow{2}{*}{ Month } & \multicolumn{5}{|c|}{ Trial 1 by grass ${ }^{1}$} & \multicolumn{4}{|c|}{ Trial 2 by grass ${ }^{1}$} & \multirow{2}{*}{ Mean ${ }^{2}$} \\
\hline & $\mathrm{T}$ & $\mathrm{S}$ & $\mathrm{P}$ & $\mathrm{D}$ & G & S & $\mathrm{P}$ & $\mathrm{D}$ & G & \\
\hline & \multicolumn{10}{|c|}{$\%$} \\
\hline April & 6.3 & 6.2 & 4.8 & 7.8 & 2.6 & 2.1 & 1.9 & 2.4 & 1.7 & 3.7 \\
\hline May & $4.0^{* 3}$ & 4.2 & 5.0 & $6.6^{*}$ & $3.6^{*}$ & 3.7 & 3.0 & 4.1 & 2.3 & 4.1 \\
\hline June & $4.0^{*}$ & $2.4^{*}$ & $2.9^{*}$ & $3.8^{*}$ & $3.9^{*}$ & 4.4 & 3.0 & 4.6 & 4.5 & 3.7 \\
\hline July & $4.4^{*}$ & $5.3^{*}$ & $4.7^{*}$ & $3.5^{*}$ & $4.1^{*}$ & 4.4 & 4.1 & 6.6 & 3.8 & 4.6 \\
\hline August & 5.9 & $3.6^{*}$ & 5.4 & 4.5 & $3.2^{*}$ & 5.6 & 4.4 & 5.4 & 9.2 & 5.2 \\
\hline September & 4.5 & $3.2^{*}$ & 3.2 & 6.6 & $3.1^{*}$ & 4.6 & 3.7 & 5.6 & 6.0 & 4.5 \\
\hline October & 5.8 & $5.1^{*}$ & 4.7 & 6.3 & $4.0^{*}$ & 6.1 & 3.8 & 5.9 & 4.3 & 5.0 \\
\hline November & 5.4 & $5.6^{*}$ & 8.1 & 8.9 & $4.6^{*}$ & 5.0 & 3.6 & 6.7 & 4.8 & 5.9 \\
\hline December & 3.9 & 3.4 & 3.3 & 6.8 & 5.0 & 3.7 & 5.0 & 5.7 & 3.5 & 4.6 \\
\hline January & 7.1 & 5.1 & 5.5 & 8.2 & 4.3 & 3.7 & 3.5 & 5.1 & 3.2 & 4.8 \\
\hline February & 7.4 & 7.4 & 7.8 & 12.9 & 5.4 & $2.5^{*}$ & $3.2^{*}$ & 2.9 & $1.6^{*}$ & 5.5 \\
\hline March & 4.3 & 6.6 & 5.8 & 10.5 & 3.9 & $1.9^{*}$ & $2.2^{*}$ & 3.7 & $1.5^{*}$ & 4.5 \\
\hline April & 7.5 & 9.7 & 6.1 & 14.4 & 5.0 & - & - & - & - & - \\
\hline Mean & 5.4 & 5.2 & 5.2 & 7.8 & 4.1 & 4.0 & 3.5 & 4.9 & 3.9 & - \\
\hline
\end{tabular}

${ }^{1}$ T, Tanner; S, Signal; P, Pangola; D, Digitaria milanjiana; G, Guinea.

${ }^{2}$ Average for 4 grasses common to both trials.

${ }^{3}$ Designates periods when put and take heifers were used. 
DAILY INTAKE OF PASTURE GRASS DRY MATTER

PGDM needed for maintenance and growth were calculated by 28-day periods. Total digestible nutrients (TDN) content was estimated from $\mathrm{CP}$ content of HP samples. In vitro true digestibility (IVTDDM) was also determined from $\mathrm{CP}$ content of $\mathrm{HP}$ samples with the regression equation of Arroyo-Aguilú and Coward-Lord (2) from forages in Puerto Rico: \%IVTDDM $=44.78+1.74 \%$ CP. Apparent digestibility was derived as $\% \mathrm{ADDM}=\% \mathrm{IVTDDM}-12.9 \%$. Intake for maintenance $=(.077)$ $\left(\mathrm{BW}^{0.75}\right) \frac{1}{(3.6155)} \frac{1}{(\mathrm{TDN})}$ and intake for gain $=(.05603 \mathrm{ADG})+(.01265$ $\left.\mathrm{ADG}^{2}\right)\left(\mathrm{wt}^{0.75}\right) \frac{1}{(.25)} \frac{1}{(3.6155)} \frac{1}{(\mathrm{TDN})}$.

Estimated TDN content of the grasses ranged from 56.7\% for Signal to $61.6 \%$ for Tanner. On the basis of TDN values, intake of $\%$ body weight (BW) (kg PGDM/kg BW) ranged from 2.9 for heifers grazing Tanner and Guinea grasses to 3.1 for those on Digitaria milanjiana and Pangola grasses in both trials. Intake differences among grasses were non-significant. The underlying assumption of the values for intake was that TDN content was closely related to intake. However, it is likely that physical rather than chemical factors (energy and protein), were acting to regulate voluntary intake. More variation in intake occurred between periods than among grasses. Although it is doubtful that fluctuations in ADG by testers was as highly correlated. with intake as assumed, intakes were just slightly higher than those reported for other tropical areas $(16,17,18)$.

The close similarity among grasses for intake based on BW showed that, although wide fluctuations may occur between periods within year, intake will not deviate markedly from $3.0 \% \mathrm{BW}$. Three percent per unit of BW exceeds the normally assumed 2.0 to $2.5 \% \mathrm{BW}$ intake by 200 - to $300-\mathrm{kg}$ heifers (15). However, to achieve the gains recorded, intake would need to exceed $2.5 \% \mathrm{BW}$, or the diet selected must be higher than estimated from the samplings.

\section{UTILIZATION OF PASTURE GRASS DRY MATTER}

Values for total intake of PGDM in 28-day periods and estimated available PGDM per animal day (table 8) were used for estimates of utilization (EU): \%EU $=[(\mathrm{PGDM}$ intake/day)/(available PGDM per period) $] \times 100$. The $E U$ by periods and grasses for trials 1 and 2 appear in table 9. Variations within grasses were greater than between grasses. On the basis of the monthly means for the four grasses used in 1972 and 1973, seasonal trends on utilization are less evident than for other measures.

PGDM of Digitaria milanjiana was highest in overall percent utiliza- 
tion in both trials (table 9). Although the superiority of this grass in animal gains was not statistically significant, it evidently has physical and/or chemical characteristics more acceptable to grazing animals in spite of below average availability of PGDM (table 8).

The objective of adding PT heifers with testers was to maintain uniformity of available PGDM. If the additions of heifers coincided with increased PGDM, no change in rate of utilization would be expected. In both trials, the effect of PT method of management on percent utilization was variable (table 10). The low utilization in most months indicated that better use was not made of PT heifers to maintain PGDM utilization

TABLE 10.-Estimated available crude protein in trials 1 and 2

\begin{tabular}{|c|c|c|c|c|c|c|c|c|c|c|}
\hline \multirow{2}{*}{ Month } & \multicolumn{5}{|c|}{ Trial 1 by grass ${ }^{1}$} & \multicolumn{4}{|c|}{ Trial 2 by grass ${ }^{1}$} & \multirow{2}{*}{ Mean $^{2}$} \\
\hline & $\mathrm{T}$ & $\mathrm{s}$ & $\mathrm{P}$ & $\mathrm{D}$ & G & S & $\mathrm{P}$ & $\mathrm{D}$ & G & \\
\hline & \multicolumn{10}{|c|}{$\mathrm{kg} /$ animal day } \\
\hline April & $13.2^{3}$ & 11.6 & 20.2 & 13.5 & 13.2 & 26.8 & 33.9 & 22.2 & 27.8 & 21.1 \\
\hline May & $15.2^{* 4}$ & 16.3 & 18.9 & $15.8^{*}$ & $15.2^{*}$ & 19.2 & 25.9 & 20.0 & 24.6 & 19.4 \\
\hline June & $16.3^{*}$ & $17.2^{*}$ & $21.4^{*}$ & $18.2^{*}$ & $16.3^{*}$ & 19.2 & 28.0 & 22.9 & 23.2 & 20.8 \\
\hline July & $10.4^{*}$ & $11.4^{*}$ & $13.5^{*}$ & $16.6^{*}$ & $10.4^{*}$ & 14.1 & 15.7 & 11.8 & 11.7 & 13.1 \\
\hline August & 7.4 & $11.3^{*}$ & 13.1 & 15.8 & 7.4 & 11.9 & 15.6 & 10.1 & 11.1 & 12.0 \\
\hline September & 13.0 & $17.0^{*}$ & 17.4 & 13.3 & 13.0 & 15.6 & 20.2 & 17.1 & 17.9 & 16.4 \\
\hline October & 12.7 & $13.0^{*}$ & 17.8 & 11.3 & 12.7 & 18.7 & 25.2 & 16.8 & 22.3 & 17.2 \\
\hline November & 12.3 & $14.4^{*}$ & 17.4 & 11.8 & 12.3 & 15.2 & 19.0 & 12.9 & 13.2 & 14.5 \\
\hline December & 12.4 & 14.2 & 15.8 & 10.6 & 12.4 & 13.5 & 16.4 & 13.1 & 18.6 & 14.3 \\
\hline January & 14.7 & 13.6 & 17.1 & 11.0 & 14.7 & 15.1 & 16.5 & 12.3 & 19.5 & 15.0 \\
\hline February & 15.7 & 15.0 & 15.7 & 12.2 & 15.7 & $18.7^{*}$ & $23.2^{*}$ & 21.3 & $23.2^{*}$ & 18.1 \\
\hline March & 17.7 & 17.7 & 16.5 & 10.6 & 17.7 & $24.2^{*}$ & $22.4^{*}$ & 20.6 & $31.7^{*}$ & 20.2 \\
\hline April & 24.2 & 18.6 & 25.6 & 14.8 & 24.2 & - & - & - & - & - \\
\hline Mean & 14,2 & 14.7 & 17.7 & 13.5 & 14.2 & 17.7 & 21.8 & 16.8 & 20.4 & 一 \\
\hline
\end{tabular}

${ }^{1}$ T, Tanner; S, Signal; P, Pangola; D, Digitaria milanjiana; G, Guinea.

${ }^{2}$ Average for 4 grasses common to both trials.

${ }^{3}$ Estimated from total pasture grass dry matter and animal days per 28-day period.

${ }^{4}$ Designates periods when put and take heifers were used.

more uniform. From a period-by-period comparison, it appeared that to maintain ADG of .45-.55 kg, percent utilization must be greater than $3 \%$ of available PGDM. Underutilization may reduce intake because of rise in CW content (20).

On the average, less than 6\% of available PGDM was utilized. Considering the costs of such factors as land, pasture establishment, fertilizer, lime, fencing, and labor, such low rate of utilization does not appear economical. Increasing utilization by higher stocking rates or by harvesting for feeding as hay, green chop or silage would reduce the degree of selectivity and also likely reduce ADG. There was usually a 6-percent 
difference between CP content of plucked samples (16.4\%) and of harvested samples (10.4\%). A similar differential between upper layers of the sward and the whole plant would be expected for TDN content and possibly for mineral and vitamin contents $(1,2)$. Thus, there must be a compromise between maximum utilization of PGDM and rate of ADG desired. The relative costs of the various inputs involved in producing forage and the expected level of animal performance in relation to value of animal products produced at various levels of utilization will determine where the optimum lies.

\section{CONCLUSIONS}

It is concluded from this study that, under heavy fertilization, Guinea, Pangola, Digitaria milanjiana, and Signal grasses can provide a satisfactory source of forages for growing heifers. Tanner grass is acceptable in $\mathrm{DM}$ and CP yields, but may cause toxicity problems. Under normal temperature and rainfall distribution, maximum temperature can be used to predict DM grass production. However, predictions may be markedly influenced by rainfall distribution. Due to variations in nutritive quality with grass height, neither whole plant nor HP samples were closely related to ADG of grazing animals. Opportunity for selection is important in ADG of animals, and careful management rotation of animals is required for good utilization of tropical grasses. CW content of grasses may be more useful than DM or CP content for assessing nutritive value. Evaluations of grasses with grazing animals should encompass the entire year in order to predict seasonal effects. Wide fluctuations in animal gains make it difficult to evaluate the merits and limitations of grasses. With lower animal performance on the selected cultivar of Guinea grass than in previous trials, agronomists should be cautioned to base their selections on more than total DM quality. Further studies on stocking rates are needed to utilize effectively a greater proportion of grass biomass without significant losses in animal ADG.

\section{RESUMEN}

Se realizaron 2 pruebas de 1 año cada una, en la Subestación Experimental Agrícola de Corozal para determinar la disponibilidad de cinco pastos: Tanner (Brachiaria radicans), Signal (Brachiaria decumbens), Pangola (Digitaria decumbens), Digitaria milanjiana y Guinea (Panicum maximum), como fuentes de forraje pastado para novillas Holstein en crecimiento. Los efectos de las diversas especies en la ganancia diaria media (ADG) (amplitud de .43 a $.51 \mathrm{~kg}$ ) no fueron significativos. El pasto Digitaria milanjiana fue el mejor en ganancia diaria media, siendo el Signal el que se estima que más cabezas puede mantener, 5.87 versus 5.2 a 5.7 cabezas/ha y año para los otros cuatro 
pastos. Se obtuvieron variaciones altas en GDP, tanto entre especies como entre meses. De diciembre a enero, la ADG fue aproximadamente $50 \%$ más baja debido a efectos de temperatura en el crecimiento de los pastos. Se consideran los cinco pastos como aceptables para el crecimiento de las novillas. Sin embargo, el pasto Tanner no se recomienda per su posible toxicidad. Los contenidos de materia seca (DM) y de proteína bruta (CP) fueron más altos en abril pero más bajos en septiembre. El contenido de DM varió de $<20$ a $>30$, demostrando su influencia en el consumo. En julio y agosto, los tres pastos arrojaron un medio de $<7 \% \mathrm{CP}$, lo cual posiblemente afectó el consumo. Con temperatura y lluvia normales, la temperatura máxima se correlaciona positiva y significativamente $(P<.01)(.64$ a .87) con el contenido de DM y negativamente $(-.26$ a -.79$)$ con el contenido de CP. Sin embargo, la precipitación anormal tuvo un efecto marcado en estas relaciones. Se obtuvieron correlaciones variables entre el contenido de DM o de CP en muestras cosechadas y la ADG, indicando que estas medidas eran relativamente poco confiables para producir ganancia. El consumo estimado de DM en términos de porcentaje peso corporal varió de 2.9 a $3.1 \%$. En promedio, se utilizo $<6 \%$ de DM de pasto disponible. Con relación a costos, una razón de uso tan baja no parece económica, por lo cual, se sugiere más investigación en el manejo y abonamiento de pastos tropicales para un uso más eficiente de la biomasa disponible.

\section{LITERATURE CITED}

1. Arroyo-Aguilú, J. A. and Coward-Lord, J., 1974. Mineral composition of 10 tropical forage grasses in Puerto Rico, J. Agric. Univ. P. R. 58 (4): 426-36.

2. —— and — , 1974. Relationships between and within physical and chemical constituents and in vitro true digestibility in tropical forage grasses, J. Agric. Univ. P. R. 58 (4): $437-47$.

3. __ and Rivera-Brenes, L., 1961. Digestibility studies on Napier (Merker) grass (Pennisetum purpureum), Giant Pangola grass (Digitaria valida Stent) and Signal grass (Brachiaria brizantha), J. Agric. Univ. P. R. 45 (3): 151-6.

4. - - Tessema, S., McDowell, R. E., VanSoest, P. J., Ramírez, A., and Randel, P. F., 1975. Chemical composition and in vitro digestibility of five heavily fertilized tropical grasses in Puerto Rico, J. Agric. Univ. P. R. 59 (3): 186-98.

5. Caro-Costas, R., 1980. Weight gains of cows fed on five grass pastures intensively managed in the humid hill region of Puerto Rico, J. Agric. Univ. P. R. 64 (1): 43-6.

6. _- Abruña, F. and Vicente-Chandler, J., 1973. Comparison of heavily fertilized Pangolagrass and Stargrass pastures under humid tropical conditions, Agron. J. 65 (1): 132-3.

7. —-, Vicente-Chandler, J., and Abruña, F., 1976. Comparison of heavily fertilized Congo, Star and Pangola grass pastures in the humid mountain region of Puerto Rico. J. Agric. Univ. P. R. 60(2): 179-85.

8. Deinum, B., 1966. Climate, nitrogen and grass, Research into the influence of light intensity, temperature, water supply and nitrogen on the production and chemical composition of grass. Meded. Land., Wageningen, Ned. 66 (11). 
9. Draper, N. R. and Smith, H., 1966. Applied regression analysis, John Wiley and Sons, Inc., New York, N.Y.

10. Hardison, W. A., Reid, J. T., Martin, C. M., and Woolfolk, P. G., 1954. Degree of herbage selection by grazing cattle, J. Dairy Sci. 37:89-102.

11. Humphreys, L. R., 1978. Tropical pasture and fodder crops, Intermediate Tropical Agriculture Series, Longmans, London, Eng.

12. Johnstone-Wallace, D. B., and Kennedy, K., 1974. Grazing management practices and their relationship to the behaviour and grazing habits of cattle, J. Agric. Sci. 34:1907.

13. McDowell, R. E., Cestero, H., Rivera-Anaya, J. D., Román-García, F., Arroyo-Aguilú, J. A., Berrocal, C. M., Soldevila, M., López-Alberty, J. C., and Metz, S. W., 1975. Tropical grass pastures with and without supplement for lactating cows in Puerto Rico, Agric. Exp. Stn. Univ. P. R., Bull. 238.

14. McDowell, R. E., 1972. Improvement of livestock production in warm climates, W. H. Freeman \& Co., San Francisco, CA.

15. National Research Council, 1978. Nutrient requirements of dairy cattle, 5th rev. ed, Nat. Acad. Sci., Washington, D. C.

16. Okorie, I. I., Hill, D. H., and McIlroy, R. J., 1965. The productivity and nutritive value of tropical grass/legume pastures rotationally grazed by N'Dama cattle at Ibadan, Nigeria, J. Agric. Sci. 64:235-45.

17. Oyenuga, V. A. and Olubajo, F. O., 1966. Productivity and nutritive value of tropical pastures at Ibadan, Proc. Xth Inter. Grassland Congr. 962. (Abstr.).

18. Smith, C. A., 1970. The feeding value of tropical grass pastures evaluated by cattle weight gains, Proc. XIth Inter. Grassland Congr. 839. (Abstr.).

19. Snedecor, G. W. and Cochran, W. G., 1967. Statistical methods, 6th ed, The Iowa State University Press, Ames, IA.

20. Tayler, J. C. and Deriaz, R. E., 1963. The use of rumen-fistulated steers in the direct determination of nutritive value of ingested herbage in grazing J. Brit. Grassland Soc. 18:29-38.

21. VanSoest, P. J., 1981. Nutritional ecology of the ruminant, O \& B Books, Corvallis, OR.

22. Vicente-Chandler, J., Abruña, F., Caro-Costas, R., Figarella, J., Silva, S., and Pearson, R. W., 1974. Intensive grassland management in the humid tropics of Puerto Rico, Agric. Exp. Stn. Univ. P. R., Bull. 233.

23. Vicente-Chandler, J., Caro-Costas, R., Pearson, R. W., Abruña, F., Figarella, J., and Silva, S., 1964. The intensive management of tropical forages in Puerto Rico, Agric. Exp. Stn. Univ. P. R., Bull, 187.

24. Yazman, J. A., 1980. Influence of supplementary feeding on growth of heifers and milk yield of lactating cows in a tropical environment, Ph.D. Thesis, Cornell University, Ithaca, N. Y.

25. —-, McDowell, R. E., Cestero, H., Arroyo-Aguilú, J. A., Rivera-Anaya, J. D., Soldevila, M., and Román-García, F., 1982. Efficiency of utilization of tropical grass pastures by lactating cows with and without supplement, J. Agric. Univ. P. R. 66 (3): 200-23. 